\title{
The relationship between P53 and EGFR expression with development and progression of endometrial cancer
}

\author{
Zainab Abdulrazzaq Hameed ${ }^{1}$, Kareem Hamed Ghali ${ }^{2}$ \\ ${ }^{I}$ (College of Medicine/ WasitUniversity, Iraq) \\ ${ }^{2}$ (Department of Biology, College of Science/ Wasit University, Iraq)
}

\begin{abstract}
Endometrial carcinoma (EC) is the most widespread gynecologic malignancy and occupies fourth most common malignancy in women.The study included thirty samples of endometrial cancer's patients .The samples were divided to groups according to staging, grading, muscles and lymph nodes invasiveness and histological types of cancer cells. This study was carried out in Laboratories of the College of Sciencel Department of Biology, Wasit University, during period between October 2015 and April 2016.Immunohistochemical technique was used to detection p53 and EGFR expression. We aimed to determine the relationships between p53 and EGFR expression with the histopathological variables involving, stage, grade, muscle and lymph nodes invasiveness and histological types. The results showed highly significant difference of p53 expression according to histological type, as well intensity with stage $(P<0.05)$. Expression and intensity of EGFR showed no significant relationship with all those pathological parameters $(P>0.05)$.

The study suggests no relationship between $p 53$ and EGFR expression with development and progression of endometrial cancer.

Keywords: Endometrial cancer, Immunohistochemistry, P53, EGFR.
\end{abstract}

\section{Introduction}

Endometrial carcinoma is the fourth most common malignancy in females, it widespread malignancy in the womanly genital tract [1]. More than $90 \%$ of cases of endometrial cancer happen in women $>50$ years of age, with a median age at diagnosis of 63years, however, $4 \%$ of women with endometrial cancer are younger than 40 years old [2]. Endometrial cancer is generally not considered a significant risk under the age of 35. However, in females presenting with an ovulatory cycles, up to $14 \%$ of will be diagnosed with hyperplasia with atypia or endometrial cancer[3].As many females are diagnosed at an early stage, most females with EC will not die from their cancer, the leading because of death $(36 \%)$ in the whole population is indeed cardiovascular disease ,however, in females dying during 5 years of their diagnosis ,most females die of disease[4].Endometrial are divided into two subtypes:type I estrogen-dependent which is the extremely common endometriosis adenocarcinoma (80\%-90\%) and arise in a background of endometrial hyperplasia, happen in the early postmenopausal interval, usually are low grade, and have a good prognosis, depended on the degree of differentiation, endometriod adenocarcinomas are divided into three grades: Grade 1, well differentiated; grade 2, moderately differentiated; and grade 3, poorly differentiated tumors[5]. Type II the fewer common clinically aggressive, include non-endometriosis subtypes such as serous papillary, clear cell have no related with estrogen excess or atypical hyperplasia, usually happen in older females, carry a worse prognosis, all type II cancers and grade 3 endometriod tumors are categorized as high-grade tumors and are related with a poor prognosis[6].Endometrial carcinoma (EC) can be classified as high-risk EC (high grade or stage $\geq \mathrm{IB}$ ) and low-risk EC (low grade and stage IA). Parameters that effect prognosis and survival are: the stage of disease at diagnosis, histological grade, deepness of myometrial invasion, lymphovascular invasion, and lymph node status,grade and histological type. The deepness of myometrial invasion are related with poor survival and a high spread of pelvic and para-aortic lymph node metastases [7]. Approximately $75 \%$ of females with EC are diagnosed with stage I disease owing early symptoms. The average 5-year survival rate for stage I is $85 \%$, for stage II is $70 \%$, for stage III is 50\%, and for stage IV is 18\%[8]. P53 gene is often mentioned as the "guardian of the genome", it is maybe one of the most essential tumor suppressor genes, and it is sited in the center of a complex of signaling methods that stop proliferation and survival of potentially malignant cells [9].A many of clinic researches have reported that p53 mutations are closed association with the endometrial carcinogenesis, and mutated p53 as a nonfunctional protein amasses in the cells (mostly in nucleus) act as a control negative inhibitor of wild-kind p53, leading to the work loss of G1 arrest, resulting in stopping apoptosis of cancer cells [10].Epidermal growth factor (EGF) motivates cell growth, proliferation and variation in several tissues by binding to its receptor EGFR [11]. EGFR overexpression did not impact disease progression in type I endometriod tumors, although impact disease progression in type II non-endometriod tumors [12].Mutation of the EGFR gene is an essential biomarker for valuation of the effect of gefitinib, a molecular-of gefitinib, a molecular-targeted drug. Personalized medicine 
based on single changes among patients is attainable using therapy strategy with anticancer drugs selected based on prediction of effects and adverse reactions using these biomarkers [13].

\section{2-1 Patients and tissue samples}

\section{Materials and methods}

All specimens of patients were collected from Al-Zahraa and AL-Karama Teaching Hospitals in Wasit Province, and form Ibn Al-BitarPrivate Laboratory in Thi Qar Province.Fixed paraffin embedded tissue blocks were cut into $4-5 \mu \mathrm{m}$ thickness from each tissue block.

\section{2-2 Immunohistochemistry (IHC):}

P53 and EGFR antibodies and ABC staining system (mouse monoclonal antibody) were provided by Santa Cruze Biotech. Inc. Serial tissue sections were cut $4-5 \mu \mathrm{m}$ thick and positioned on positive charged slides. The slides were baked in $60-65^{\circ} \mathrm{C}$ oven overnight.The tissue sections were deparaffinized; then the slides were rehydrated by graded ethanol concentration $(100 \%, 95 \%$, and $70 \%)$ andxylene concentration (100\%) and distal water.The slides were treated with citrate buffer for 10 minutes, and then washed twice in distal water for 2 minutes. After preparation of tissue sections, slides were incubated in $3 \%$ hydrogen peroxide $(\mathrm{H} 2 \mathrm{O} 2)$ diluted in D.W. for 7 minutes.Each slide was washed in PBS twice for 5 minutes.Sections were incubated for one hour in $1.5 \%$ blocking serum diluted with PBS.This step may be omitted if non-specific staining is not a problem.Primary antibody (prepared by adding $1 \mu \mathrm{l}$ of the primary to $50 \mu \mathrm{l}$ of $1.5 \%$ blocking serum diluted in PBS) was applied for 30 minutes at room temperature or overnight at $4^{\circ} \mathrm{C}$.Slides were washed with three changes of PBS for 5 minutes each, and then slides were incubated for 30 minutes with biotinylated secondary antibody and washed with two times of PBS for 5 minutes. Sections were incubated for 30 minutes with AB enzyme reagent, after that washed with two times of PBS for 5 minutes each.Sections were incubated in 1-3 drops peroxidase substrate for 9 minutes.The sections may be checked for staining by rinsing with $\mathrm{H} 2 \mathrm{O}$ and viewing under a microscope (if necessary added additional peroxidase substrate), then sections were washed one time in distilled water for 5 minutes.Counter stain slides, Hematoxylin stain was added on slides for 43 seconds. Immediately, slides rinsed with running tap water for 2 minutes.Dehydrated sections as follows: $1 \mathrm{x}$ 95\% ethanol for 20 seconds and free ethanol at 2 times for 20 seconds and xylene at 1 time for 10 seconds.Immediately 1-2 of DPX solution was added and cover with glass coverslip. Finally, slides were observed by light microscope.

\section{2-3 Ethical consent}

The study was submitted and approved by the College of Science, University of Wasit in collaboration with AL-Karama and AL-Zahraa Teaching Hospitals, Wasit - Iraq.

\section{2-4 Statistical analysis}

For all statistical analyses, the SPSS system for personal computer was used, and p values of 0.05 or less were regarded as statistically significant. Sensitivity and specificity of the tests (with $95 \%$ exact confidence intervals) were determined in studied group. Comparison between groups was carried out using Chi-square test.

\section{2-5 Scoring system}

Based on the percentage of stained cells and the intensity of nuclear stain .The staining of p53 and EGFR were scored as follows: The percentage of positive staining (P) was scored as 0 for negative, 1 for $1-25 \%$, 2 for $26-50 \%$, and 3 for $51-100 \%$ staining, and the levels of intensity of staining (I) were scored as 0 , negative; 1 , weak staining; 2 , moderate staining; and 3 , strong staining.

\section{Results and Discussion}

\section{1:P53 expression and intensity in endometrial cancer according staging}

Immunohistochemistry (IHC) analysis was carried out to clear the relationship between p53 and EGFR expression and intensity with histopathological parameters of endometrial cancer. According to stage the results were reported that p53 expression was positive in:6(37.5\%) of stage I out of 16 cases, $4(40 \%)$ of stage II out of 16 cases, $4(100 \%)$ of stageIIIout of 4 cases, no casesin stageIV.There was no significant to p53 expression according stage $(\mathrm{P}>0.05)$. Intensity of p53 expression in endometrial cancer according to staging showed that; in stage I, $10(62.5 \%)$ cases with score $0,2(12.5 \%)$ cases with score $+1,4(25.0 \%)$ cases with score +2 and $0(0.0 \%)$ case with score +3 .In stage II,6(60.0\%) cases with score $0,0(0 \%)$ cases with score $+1,3(30.0 \%)$ cases with score $+2,1(10.0 \%)$ case with score +3 . InstageIII, $0(0 \%)$ case with score $0,+1,1(25 \%)$ case with score $+2,3(75 \%)$ cases with score +3 . While instageIV, no cases with all scores. There was highly significant to p53 intensity according stage $(\mathrm{P}<0.008)$ (Table 1). 
Table (1): P53 expression and intensity in endometrial cancer according to staging

\begin{tabular}{|c|c|c|c|c|c|c|c|c|c|}
\hline \multirow[b]{2}{*}{ Stage } & \multicolumn{2}{|c|}{ Expression } & \multirow[b]{2}{*}{$P$ value } & \multirow[b]{2}{*}{$\begin{array}{c}0 \\
\text { No\% } \\
\end{array}$} & \multicolumn{3}{|c|}{ Intensity } & \multirow[b]{2}{*}{$P$ value } & \multirow[b]{2}{*}{ Total } \\
\hline & No\% & $\begin{array}{c}+- \\
\text { No\% } \\
\end{array}$ & & & $\begin{array}{l}1 \\
\text { No\% }\end{array}$ & $\begin{array}{l}2 \\
\text { No\% } \% \\
\end{array}$ & $\begin{array}{l}3 \\
\text { No\% }\end{array}$ & & \\
\hline S I & $\begin{array}{c}6) \\
37.5 \%\end{array}$ & $\begin{array}{c}(10) \\
62.5 \%\end{array}$ & $\mathrm{P}>0.05$ & $\begin{array}{c}(10) \\
62.5 \%\end{array}$ & $\begin{array}{c}(2) \\
12.5 \% \\
\end{array}$ & $\begin{array}{c}(4) \\
25.0 \% \\
\end{array}$ & $\begin{array}{c}(0) \\
0.0 \% \\
\end{array}$ & $\mathrm{P}<0.05$ & $\begin{array}{c}(16) \\
100.0 \%\end{array}$ \\
\hline S II & $\begin{array}{c}(4) \\
40 \%\end{array}$ & $\begin{array}{c}(6) \\
60.0 \%\end{array}$ & & $\begin{array}{c}(6) \\
60.0 \%\end{array}$ & $\begin{array}{c}(0) \\
0.0 \%\end{array}$ & $\begin{array}{c}(3) \\
30.0 \%\end{array}$ & $\begin{array}{c}(1) \\
10.0 \%\end{array}$ & & $\begin{array}{c}(10) \\
100.0 \%\end{array}$ \\
\hline S III & $\begin{array}{c}(4) \\
100.0 \%\end{array}$ & $\begin{array}{c}(0) \\
0.0 \%\end{array}$ & & $\begin{array}{c}(0) \\
0.0 \%\end{array}$ & $\begin{array}{c}(0) \\
0.0 \%\end{array}$ & $\begin{array}{c}(1) \\
25.0 \%\end{array}$ & $\begin{array}{c}(3) \\
75.0 \%\end{array}$ & & $\begin{array}{c}(4) \\
100.0 \%\end{array}$ \\
\hline S IV & $\begin{array}{c}(0) \\
0.0 \%\end{array}$ & $\begin{array}{c}(0) \\
0.0 \%\end{array}$ & & $\begin{array}{c}(0) \\
0.0 \%\end{array}$ & $\begin{array}{c}(0) \\
0.0 \%\end{array}$ & $\begin{array}{c}(0) \\
0.0 \%\end{array}$ & $\begin{array}{c}(0) \\
0.0 \%\end{array}$ & & $\begin{array}{c}(0) \\
0.0 \%\end{array}$ \\
\hline Total & $\begin{array}{c}(14) \\
46.7 \%\end{array}$ & $\begin{array}{c}(16) \\
53.3 \%\end{array}$ & $\begin{array}{c}(30) \\
100.0 \%\end{array}$ & $\begin{array}{c}(16) \\
53.3 \%\end{array}$ & $\begin{array}{c}(2) \\
6.7 \%\end{array}$ & $\begin{array}{c}(8) \\
26.7 \%\end{array}$ & $\begin{array}{c}(4) \\
13.3 \%\end{array}$ & & $\begin{array}{c}(30) \\
100.0 \%\end{array}$ \\
\hline
\end{tabular}

$((\mathrm{P}<0.008$, highly significant $\mathrm{P}>0.05$, non-significant $))$

Our results showed that expression of p53 in endometrium patientsaccording stage was non-significant difference $(\mathrm{P}>0.05)$, while intensity was appeared a highly significant difference $(\mathrm{p}=0.008)$. Results of [14] showed that 7 out of 27 cases had positive expression in the low stage (stage I and II) of endometrial cancer, while in thestage(III and IV )only 10cases out of the 23cases had p53-postive endometrial cancer .Moreover, [15] found in theendometriod adenocarcinomas, stage IB 5 (13.9\%)out of 36 caseshad p53-postive , in stage IIIC $4(80.0 \%)$ out of 5 cases had p53 positive. Whileserous papillary endometrial adenocarcinomas,stage IB showed $2(100.0 \%)$ had positive, in stage IC $5(100.0 \%)$ cases had positive and, in stage IIIC $4(80.0 \%)$ out of 5 cases had positive. Also[16]showed that in thestageI, 2(5.6)cases with score 1and 4(11.1) cases with score 2.In stage II(N=12), 4(33.3)cases with score 2.In stageIII $(\mathrm{N}=17), \quad 12(70.6)$ cases with score 2. However,[17]foundp53 expression in advanced stage (IIA to IVB) more common rather than early stage (IA to IIB) endometrial carcinoma(11)55\% versus (3)15\%; (p value=0.006). As well as [18] showedthatP53 overexpression in endometrial carcinoma in the stage I, 3(13\%) cases out of $23(74.1 \%)$, instage II, $4(66.7 \%)$ out of $6(19.4 \%)$ cases, in stage III $2(100 \%)$ cases out of $2(6.5 \%)$ cases. As well as[19]found that in stage I, p53 expressionpositive in $11(36.7 \%)$ cases, in stage II,p53 expression positive in $3(75.0 \%)$ cases ,in stage III,p53 expression positive appeared in all cases $4(100 \%)$.

\section{2:P53 expression and intensity in endometrial cancer according grading}

According to grading, p53 expression was reported in:7(41.2\%) of grad I out of 17 cases, 5(55.5\%) of grad II out of 9 cases, 2 (50\%) of gradIIIout of 4 cases.Intensity of p53 expression in endometrial cancer showed that; in grad $\mathrm{I}, 10(58.8 \%)$ cases with score $0,2(11.8 \%)$ cases with score $+1,3(17.6 \%)$ cases with score +2 ,2(11.8\%) cases with score +3 . While in grade II,4(44.4\%) cases with score $0,0(0 \%)$ case with score +1 , $3(33.3 \%)$ cases with score $+2,2(22.2 \%)$ case with score +3 .In grad III,2(50.0\%) cases with score $0,0(0 \%)$ case with score +1 and +3 , and $2(50.0 \%)$ cases with score +2 . There were no significant to p53 expression and intensity in endometrial cancer according grading $(\mathrm{P}>0.05)$.According to grading, $\mathrm{p} 53$ expression was reported in:7(41.2\%) of grad I out of 17 cases, 5(55.5\%) of grad II out of 9 cases, 2 (50\%) of gradIIIout of 4 cases.Intensity of p53 expression in endometrial cancer showed that; in grad I, $10(58.8 \%)$ cases with score 0 , $2(11.8 \%)$ cases with score $+1,3(17.6 \%)$ cases with score $+2,2(11.8 \%)$ cases with score +3 . While in grade II,4(44.4\%) cases with score $0,0(0 \%)$ case with score $+1,3(33.3 \%)$ cases with score $+2,2(22.2 \%)$ case with score +3 .In grad III, $2(50.0 \%)$ cases with score $0,0(0 \%)$ case with score +1 and +3 , and $2(50.0 \%)$ cases with score +2 . There were no significant to p53 expression and intensity in endometrial cancer according grading $(\mathrm{P}>0.05)$ Table (2).

Table(2):P53 expression and intensity in endometrial cancer according to grading

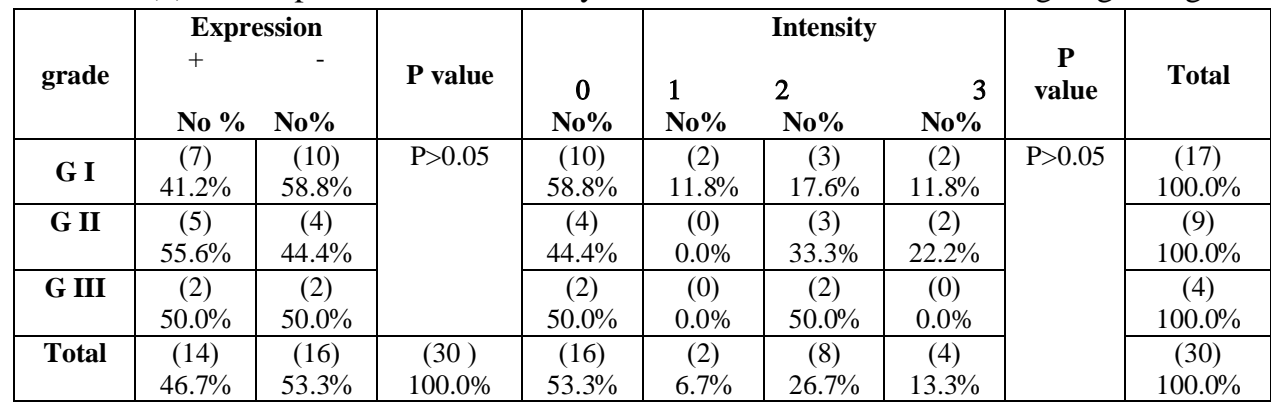


Our results showed that no significant difference to $\mathrm{p} 53$ expression and intensity according to grading $(\mathrm{P}>0.05)$. Results of[15] foundp53 expression positive was in $4(18.2 \%)$ cases of grad I out of 22,in grad II ,4 (17.4\%)casespositive forp53 expression, in grad III $1(25.0 \%)$ case was positive for p53 expression out of 4 cases (Value $=0.936$ ). However, [19] showed that: ingrad I, 3(21.4\%)caseswere positive expression for p53, ingrad II, $10(62.5 \%)$ cases were positive expression for $\mathrm{p} 53$, in grad III,5(62.5\%) caseswere positive expression for $\mathrm{p} 53$. Moreover,[16] reported all cases in grade 1 were with score $0,22(91.6 \%)$ cases out of 24 in grade II were score $0,1(4.2 \%)$ case was with score +1 and +2 , in grade III $(\mathrm{N}=23), 3(13.0 \%)$ cases were with score $0,1(4.4 \%)$ cases was with score $+1,19(82.6 \%)$ cases were with score +2 .Also[20] found thatp53 expression positive in $6(6.8 \%)$ cases of grad I, ingrad II and grad III, 25(39.1\%)cases were positive expression for p53.

\section{3:P53 expression and intensity in endometrial cancer according to muscle and lymph node invasiveness}

P53 expression and intensity in endometrial cancer according muscle invasiveness was reported among invasive endometrial cancer patients, $7(50.0 \%)$ cases of them were found to be having p53 positive, while 7 $(43.8 \%)$ cases of non-invasive were found to be p53 positive. Appreciation of p53 expression intensity in endometrial cancer in relation to invasiveness of tumor revealed that; in the invasive tumors, $7(50.0 \%)$ cases with score $0,0(0 \%)$ case with score $+1,5(35.7 \%)$ cases with score +2 and $2(14.3 \%)$ cases with score +3 . While in the non-invasive tumors, $9(56.3 \%)$ cases with score $0,2(12.5 \%)$ cases with scores +1 and $+3,3(18.8 \%)$ cases with score +2 . There were no significant to p53 expression and intensity according muscle invasiveness $(\mathrm{P}>0.05)$ Table (3).

Table(3):P53 expression and intensity in endometrial cancer according to muscle invasiveness

\begin{tabular}{|c|c|c|c|c|c|c|c|c|c|}
\hline $\begin{array}{l}\text { Muscle } \\
\text { invasion }\end{array}$ & $\begin{array}{c}\text { Expr } \\
+ \\
\text { No\% }\end{array}$ & $\begin{array}{c}\text { ession } \\
\text { No } \%\end{array}$ & $P$ value & $\begin{array}{c}0 \\
\text { No\% } \\
\end{array}$ & No\% & \begin{aligned} \multicolumn{3}{r}{ Intensity } \\
$21 \quad 3 \\
$ No\% \end{aligned} & No\% & $P$ value & Total \\
\hline Yes(14) & $\begin{array}{c}(7) \\
50.0 \%\end{array}$ & $\begin{array}{c}(7) \\
50.0 \%\end{array}$ & \multirow[t]{2}{*}{$P>0.05$} & $\begin{array}{c}(7) \\
50.0 \%\end{array}$ & $\begin{array}{c}(0) \\
0.0 \%\end{array}$ & $\begin{array}{c}(5) \\
35.7 \%\end{array}$ & $\begin{array}{c}(2) \\
14.3 \%\end{array}$ & \multirow[t]{3}{*}{$\mathrm{P}>0.05$} & $\begin{array}{c}(14) \\
100.0 \%\end{array}$ \\
\hline No(16) & $\begin{array}{c}(7) \\
43.8 \% \\
\end{array}$ & $\begin{array}{c}(9) \\
56.3 \% \\
\end{array}$ & & $\begin{array}{c}9) \\
56.3 \% \\
\end{array}$ & $\begin{array}{c}(2) \\
12.5 \% \\
\end{array}$ & $\begin{array}{c}(3) \\
18.8 \% \\
\end{array}$ & $\begin{array}{c}(2) \\
12.5 \% \\
\end{array}$ & & $\begin{array}{c}(16) \\
100.0 \% \\
\end{array}$ \\
\hline Total & $\begin{array}{c}(14) \\
46.7 \%\end{array}$ & $\begin{array}{c}(16) \\
53.3 \%\end{array}$ & $\begin{array}{c}(30) \\
100.0 \%\end{array}$ & $\begin{array}{c}(16) \\
53.3 \%\end{array}$ & $\begin{array}{c}(2) \\
6.7 \%\end{array}$ & $\begin{array}{c}(8) \\
26.7 \%\end{array}$ & $\begin{array}{c}(4) \\
13.3 \%\end{array}$ & & $\begin{array}{c}(30) \\
100.0 \%\end{array}$ \\
\hline
\end{tabular}

P53 expression and intensity in endometrial cancer according lymph node invasion was reported amonglymph node invasive endometrial cancer patients, 4(57.1\%) cases of them were found to be p53 positive, while $10(34.5 \%)$ cases of non-invasive cases were found to be p53 positive. Analysis of p53 expression intensity in endometrial cancer in relation tolymph node invasiveness of tumor revealed that; in the invasive tumors, $3(42.9 \%)$ cases with score $0,0(0.0 \%)$ case with score $+1,3(42.9 \%)$ cases with score +2 , and $1(14.3 \%)$ case with score +3 . While in the non-invasive tumors, $13(56.5 \%)$ cases with score $0,2(8.7 \%)$ cases with score +2 , $5(21.7 \%)$ cases with score +2 , and $3(13.0 \%)$ cases with score +3 . No significant relationship between p53 expression and intensity with lymph nodes invasiveness Table(4).

Table(4):P53 expression and intensity in endometrial cancer according to lymph node invasion

\begin{tabular}{|c|c|c|c|c|c|c|c|c|c|}
\hline $\begin{array}{l}\text { lymph } \\
\text { node }\end{array}$ & \multicolumn{2}{|c|}{$\begin{array}{c}\text { Expression } \\
+- \\
\text { No\% N0\% }\end{array}$} & $P$ value & $\begin{array}{c}0 \\
\text { No\% }\end{array}$ & $\begin{array}{l}1 \\
\text { No\% } \%\end{array}$ & $\begin{array}{c}\text { Intensit } \\
2 \\
\text { No\% }\end{array}$ & $\begin{array}{c}3 \\
\text { No\% }\end{array}$ & $\begin{array}{c}P \\
\text { value }\end{array}$ & Total \\
\hline $\operatorname{Yes}(7)$ & $\begin{array}{c}(4) \\
57.1 \%\end{array}$ & $\begin{array}{c}(3) \\
42.9 \%\end{array}$ & $P>0.05$ & $\begin{array}{c}(3) \\
42.9 \%\end{array}$ & $\begin{array}{c}(0) \\
0.0 \%\end{array}$ & $\begin{array}{c}(3) \\
42.9 \%\end{array}$ & $\begin{array}{c}(1) \\
14.3 \%\end{array}$ & $\mathrm{P}>0.05$ & $\begin{array}{c}(7) \\
\% 100.0\end{array}$ \\
\hline $\operatorname{No}(23)$ & $\begin{array}{c}(10) \\
34.5 \%\end{array}$ & $\begin{array}{c}(13) \\
56.5 \%\end{array}$ & & $\begin{array}{c}(13) \\
56.5 \%\end{array}$ & $\begin{array}{c}(2) \\
8.7 \%\end{array}$ & $\begin{array}{c}(5) \\
21.7 \%\end{array}$ & $\begin{array}{c}(3) \\
13.0 \%\end{array}$ & & $\begin{array}{c}(23) \\
\% 100.0\end{array}$ \\
\hline Total & $\begin{array}{c}(14) \\
46.7 \%\end{array}$ & $\begin{array}{c}(16) \\
53.3 \%\end{array}$ & $\begin{array}{c}(30) \\
100.0 \%\end{array}$ & $\begin{array}{c}(16) \\
53.3 \%\end{array}$ & $\begin{array}{c}(2) \\
6.7 \%\end{array}$ & $\begin{array}{c}(8) \\
26.7 \%\end{array}$ & $\begin{array}{c}(4) \\
13.3 \%\end{array}$ & & $\begin{array}{c}(30) \\
\% 100.0\end{array}$ \\
\hline
\end{tabular}

$(\mathrm{P}>0.05$, non-significant)

( $\mathrm{P}>0.05$,non- significant $)$

Also our results showed no significant to p53 expression and intensity according to muscle and lymph node invasiveness ( $\mathrm{P}>0.05$ ) (Table 3 and 4).Results of[19] showed in no myometrial invasion p53 expression was positive in $2(33.3 \%)$ cases out of 6 , while in invasion $<50 \%$, p53 expression was positive in $8(47.1 \%)$ 
and in $7(46.7 \%)$ cases with muscle invasion and p53 expression positive in $8(46.7 \%)$ cases out of 15 (100\%).Moreover, [20] showed that in less than half myometrial invasion, , p53 expression positive in 16 $(13.9 \%)$ cases. While in more than half in invasive muscle,p53 expression positive in $15(40.5 \%)$ cases. On the other hand, results of [14] found that in lymph node invasion p53expression positive in 5 cases out of 10, while innon-invasive p53 expression was positive in 11 out of30 cases. Moreover,[20]explained thatin lymph node invasionp53 expression positive in 7 (46.7\%), while in non-invasive p53 expression positive in 20 (18.2\%) . [21] reported thatp53 expression positive in patients with lymph nodes invasion were $3(23.1 \%$ ) cases with score 0,5 $(38.5 \%)$ caseswith score $+1,3(23.1 \%)$ cases with score +2 , and 2(15.4\%) cases with score +3 .In addition.

\section{4: P53 expression and intensity in endometrial cancer according histological type}

Regarding to p53 expression according to histological cell types(Fig 1), the results reported that $6(85.7 \%)$ out of 7 cases positive in papillary, 7(35.0\%) out of 20 cases positive in endometriod,patients ofsquamous cell carcinoma(SCC)have not p53 expression, and expression of p53 was positive in mucinous $1(100 \%)$ case. These results showedsignificantfor p53 expression in endometrial cancer according histological type $(\mathrm{P}<0.01)$.Intensity assessment of p53 expression in endometrial cancer according histological type showed that; in papillary $1(14.3 \%)$ case was scored 0 , no cases with score +1 , and highest percentage $4(57.1 \%)$ cases with score +2 , and $2(28.6 \%)$ cases were scored +3 . While in endometriod $13(65.0 \%)$ cases were scored 0 , $2(10.0 \%)$ cases were scored $+1,4(20.0 \%)$ cases were scored +2 , and $1(5.0 \%)$ case was scored +3 . While in mucinous $1(100 \%)$ case showed score +3 . These results showedno significantfor p53 intensityin endometrial cancer according histological type $(\mathrm{P}>0.05)$ Table (5).

Table(5):p53 expression and intensity in endometrial cancer according to histological type

\begin{tabular}{|c|c|c|c|c|c|c|c|c|c|}
\hline $\begin{array}{c}\text { Histological } \\
\text { type }\end{array}$ & $\begin{array}{r}\quad \text { Exp } \\
+\quad \text { No } \%\end{array}$ & $\begin{array}{l}\text { sion } \\
\text { No\% }\end{array}$ & $P$ value & $\begin{array}{c}0 \\
\text { No\% }\end{array}$ & 1 No\% & $\begin{array}{c}\text { Intensi } \\
\quad 2 \\
\mathrm{No}\end{array}$ & $\begin{array}{c}3 \\
\text { No\% }\end{array}$ & $P$ value & Total \\
\hline Papillary & $\begin{array}{c}(6) \\
85.7 \%\end{array}$ & $\begin{array}{c}(1) \\
14.3 \%\end{array}$ & \multirow[t]{4}{*}{$\mathrm{P}<0.05$} & $\begin{array}{c}(1) \\
14.3 \%\end{array}$ & $\begin{array}{c}(0) \\
0.0 \%\end{array}$ & $\begin{array}{c}(4) \\
57.1 \%\end{array}$ & $\begin{array}{c}(2) \\
28.6 \%\end{array}$ & \multirow[t]{5}{*}{$\mathrm{P}>0.05$} & $\begin{array}{c}(7) \\
100.0 \%\end{array}$ \\
\hline Endometriod & $\begin{array}{c}(7) \\
35.0 \%\end{array}$ & $\begin{array}{c}(13) \\
65.0 \%\end{array}$ & & $\begin{array}{c}(13) \\
65.0 \%\end{array}$ & $\begin{array}{c}(2) \\
10.0 \%\end{array}$ & $\begin{array}{c}(4) \\
20.0 \%\end{array}$ & $\begin{array}{c}(1) \\
5.0 \%\end{array}$ & & $\begin{array}{c}(20) \\
100.0 \%\end{array}$ \\
\hline $\begin{array}{c}\text { squamous cell } \\
\text { carcinoma }\end{array}$ & $\begin{array}{c}(0) \\
0.0 \% \\
\end{array}$ & $\begin{array}{c}(2) \\
100.0 \% \\
\end{array}$ & & $\begin{array}{c}(2) \\
100.0 \% \\
\end{array}$ & $\begin{array}{c}(0) \\
0.0 \% \\
\end{array}$ & $\begin{array}{c}(0) \\
0.0 \%\end{array}$ & $\begin{array}{c}0) \\
0.0 \% \\
\end{array}$ & & $\begin{array}{c}(2) \\
100.0 \% \\
\end{array}$ \\
\hline Mucinous & $\begin{array}{c}(1) \\
100.0 \%\end{array}$ & $\begin{array}{c}(0) \\
0.0 \% \\
\end{array}$ & & $\begin{array}{c}(0) \\
0.0 \% \\
\end{array}$ & $\begin{array}{c}(0) \\
0.0 \% \\
\end{array}$ & $\begin{array}{c}(0) \\
0.0 \%\end{array}$ & $\begin{array}{c}(1) \\
100.0 \%\end{array}$ & & $\begin{array}{c}(1) \\
100.0 \% \\
\end{array}$ \\
\hline Total & $\begin{array}{c}(14) \\
46.7 \% \\
\end{array}$ & $\begin{array}{c}(16) \\
53.3 \%\end{array}$ & $\begin{array}{c}(30) \\
100.0 \%\end{array}$ & $\begin{array}{c}(16) \\
53.3 \%\end{array}$ & $\begin{array}{c}(2) \\
6.7 \%\end{array}$ & $\begin{array}{c}(8) \\
26.7 \% \\
\end{array}$ & $\begin{array}{c}(4) \\
13.3 \% \\
\end{array}$ & & $\begin{array}{c}30) \\
100.0 \%\end{array}$ \\
\hline
\end{tabular}

( $\mathrm{P}>0.05$,non-significant)(significant, $\mathrm{P}=0.01)$

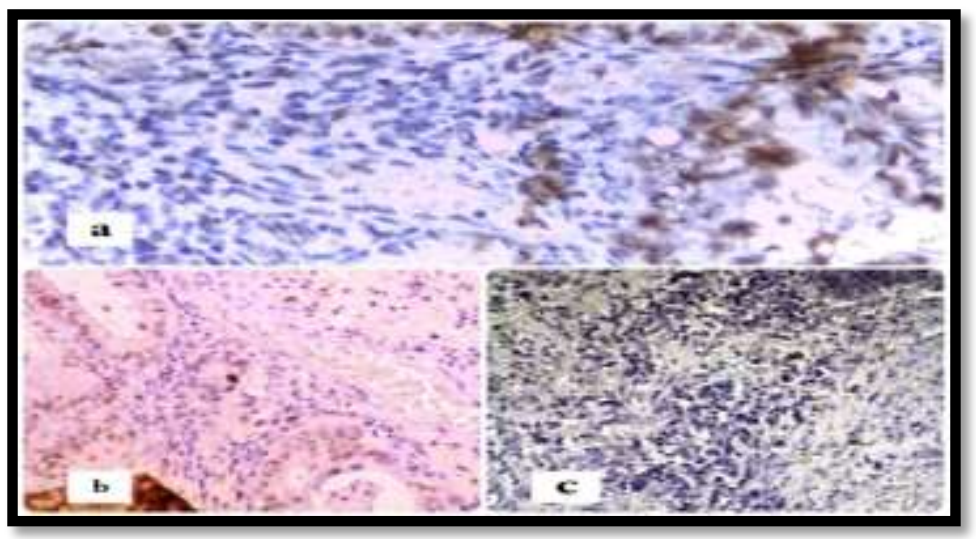

Figure(1): P53 IHC staining in endometrial patients according histological type

a. Papillary(positive), b.(positive)Endometriod, c.(negative) Squamous cell carcinoma (x40).

Our findings showedsignificantfor p53 expression in endometrial cancer according to histological type $(\mathrm{P}=0.01)$. Results of [16] found that $\mathrm{p} 53$ higher expression inendometrial serous carcinomas than endometriod carcinomas $(\mathrm{P}<0.001)$. Moreover,[22] reported that expression for p53 were seen in approximately $80 \%$ to $90 \%$ cases of serous carcinoma. Also,[23] showed that expression for p53 can be seen in endometriod adenocarcinomas $(\sim 10 \%)$ cases.Our results positivity expression for p53 were higher significant in papillary serous than endometriod carcinomas. .However, $[24]$ were explained that immunohistochemical positive for p53 
protein in squamous cell carcinoma (SCC) cells of endometrial cancer were 30\%. Also [25] showed that in mucinous tumors p53 mutation was rarely.

\section{5: EGFR expression and intensity in endometrial cancer according to staging, grading, muscles and lymph nodes invasion and histological types}

EGFR expression and intensity in endometrial cancer according stage was reported that EGFR expression was in: 11(68.8\%) of stage I out of 16 cases, 7(70\%) of stage II out of 10 cases, and $2(50.0 \%)$ of stage III out of 4 cases, no cases were reported in stage IV. Intensity of EGFR expression in endometrial cancer showed that; in stage I, 5(31.3\%) cases with score $0,1(6.3 \%)$ case with score +1 and 5(31.2\%) cases were scored +2 and +3 . In stage II,3(30.0\%) cases with score $0,+1$ and $+3,1(10.0 \%)$ case were scored +2 .In stage III, $2(50.0 \%)$ cases were scored $0,0(0 \%)$ case with score $+1,1(25.0 \%)$ case with score +2 and +3 . While in stage IV, $0(0 \%)$ case with score $0,+1,+2$ and +3 . There were no significant to EGFR expression and intensity in endometrial cancer according stage $(\mathrm{P}>0.05)$ Table (6).

Table(6):EGFR expression and intensity in endometrial cancer according to staging

\begin{tabular}{|c|c|c|c|c|c|c|c|c|c|}
\hline \multirow[b]{2}{*}{ Stage } & \multicolumn{2}{|c|}{ Expression } & \multirow[b]{2}{*}{$P$ value } & \multirow[b]{2}{*}{$\begin{array}{c}0 \\
\text { No\% }\end{array}$} & \multicolumn{3}{|c|}{ Intensity } & \multirow[b]{2}{*}{$P$ value } & \multirow[b]{2}{*}{ Total } \\
\hline & $\begin{array}{c}+ \\
\text { No\% }\end{array}$ & No $\%$ & & & $\begin{array}{r}1 \\
\text { No\% }\end{array}$ & $\begin{array}{c}2 \\
\text { No\% }\end{array}$ & $\begin{array}{c}3 \\
\text { No\% }\end{array}$ & & \\
\hline S I & (11) & (5) & $P>0.05$ & (5) & (1) & (5) & (5) & $\mathrm{P}>0.05$ & (16) \\
\hline S II & $\begin{array}{c}0.0 \% \\
(7) \\
70.0 \%\end{array}$ & $\begin{array}{c}(3) \\
30.0 \%\end{array}$ & & $\begin{array}{c}(3) \\
30.0 \%\end{array}$ & $\begin{array}{c}0.5 \% \\
30.0 \%\end{array}$ & $\begin{array}{c}\frac{1.2 \%}{(1)} \\
10.0 \%\end{array}$ & $\begin{array}{c}(3) \\
30.0 \%\end{array}$ & & $\begin{array}{c}(10) \\
100.0 \%\end{array}$ \\
\hline S III & $\begin{array}{c}(2) \\
50.0 \%\end{array}$ & $\begin{array}{c}(2) \\
50.0 \%\end{array}$ & & $\begin{array}{c}(2) \\
50.0 \%\end{array}$ & $\begin{array}{c}(0) \\
0.0 \%\end{array}$ & $\begin{array}{c}(1) \\
25.0 \%\end{array}$ & $\begin{array}{c}(1) \\
25.0 \%\end{array}$ & & $\begin{array}{c}(4) \\
100.0 \%\end{array}$ \\
\hline S IV & $\begin{array}{c}(0) \\
0.0 \%\end{array}$ & $\begin{array}{c}(0) \\
0.0 \%\end{array}$ & & $\begin{array}{c}(0) \\
0.0 \%\end{array}$ & $\begin{array}{c}(0) \\
0.0 \%\end{array}$ & $\begin{array}{c}(0) \\
0.0 \% \\
\end{array}$ & $\begin{array}{c}(0) \\
0.0 \%\end{array}$ & & $\begin{array}{c}(0) \\
0.0 \%\end{array}$ \\
\hline Total & $\begin{array}{c}(20) \\
66.7 \%\end{array}$ & $\begin{array}{c}(10) \\
33.3 \%\end{array}$ & $\begin{array}{c}(30) \\
100.0 \%\end{array}$ & $\begin{array}{c}(10) \\
33.3 \%\end{array}$ & $\begin{array}{c}4) \\
13.3 \%\end{array}$ & $\begin{array}{c}(7) \\
23.3 \%\end{array}$ & $\begin{array}{c}(9) \\
30.0 \%\end{array}$ & & $\begin{array}{c}30 \\
(100.0 \%)\end{array}$ \\
\hline
\end{tabular}

( $\mathrm{P}>0.05$,non-significant $) \quad(\mathrm{P}>0.05$, non-significant $)$

Analysis of EGFR expression and intensity in endometrial cancer according to grading was reported that EGFR expression was in:11(64.7\%) of grad I out of 17 cases, 6(66.7\%) of grad II out of 9 cases, $3(75 \%)$ of gradIIIout of 4 cases.Intensity of EGFR expression in endometrial cancershowed that; in grad I, 6(35.3\%)cases with score $0,1(5.9 \%)$ case with score $+1,4(23.5 \%)$ cases were score $+2,6(35.3 \%)$ cases with score +3 . While in grade II,3(33.3\%) cases with score $0,2(22.2 \%)$ case with score $+1,+2$ and +3 . Ingrad III, $1(25.0 \%)$ case with score $0,+1,+2$ and +3 . There were no significant to EGFR expression and intensity in endometrial cancer according grading $(\mathrm{P}>0.0)$ Table $(7)$.

Table(7):EGFR expression and intensity in endometrial cancer according to grading

\begin{tabular}{|c|c|c|c|c|c|c|c|c|c|}
\hline \multirow[b]{2}{*}{ Grad } & \multicolumn{2}{|c|}{ Expression } & \multirow[b]{2}{*}{$P$ value } & \multirow[b]{2}{*}{$\begin{array}{c}0 \\
\text { No\% }\end{array}$} & \multicolumn{3}{|c|}{ Intensity } & \multirow[b]{2}{*}{$P$ value } & \multirow[b]{2}{*}{ Total } \\
\hline & $\begin{array}{l}+ \\
\text { N0\% }\end{array}$ & No\% & & & $\begin{array}{r}1 \\
\text { No\% }\end{array}$ & $\begin{array}{r}2 \\
\text { No\% }\end{array}$ & $\begin{array}{r}3 \\
\text { No\% }\end{array}$ & & \\
\hline GI & $\begin{array}{c}(11) \\
64.7 \%\end{array}$ & $\begin{array}{c}(6) \\
35.3 \%\end{array}$ & \multirow[t]{3}{*}{$\mathrm{P}>0.05$} & $\begin{array}{c}(6) \\
35.3 \%\end{array}$ & $\begin{array}{r}(1) \\
5.9 \%\end{array}$ & $\begin{array}{c}(4) \\
23.5 \%\end{array}$ & $\begin{array}{c}(6) \\
35.3 \%\end{array}$ & \multirow[t]{4}{*}{$\mathrm{P}>0.05$} & $\begin{array}{c}(17) \\
100.0 \%\end{array}$ \\
\hline GII & $\begin{array}{c}(6) \\
66.7 \%\end{array}$ & $\begin{array}{c}(3) \\
33.3 \%\end{array}$ & & $\begin{array}{c}\text { (3) } \\
33.3 \%\end{array}$ & $\begin{array}{c}(2) \\
22.2 \%\end{array}$ & $\begin{array}{c}(2) \\
22.2 \%\end{array}$ & $\begin{array}{c}(2) \\
22.2 \%\end{array}$ & & $\begin{array}{c}(9) \\
100.0 \%\end{array}$ \\
\hline G III & $\begin{array}{c}(3) \\
75.0 \%\end{array}$ & $\begin{array}{c}(1) \\
25.0 \%\end{array}$ & & $\begin{array}{c}(1) \\
25.0 \%\end{array}$ & $\begin{array}{c}(1) \\
25.0 \%\end{array}$ & $\begin{array}{c}(1) \\
25.0 \%\end{array}$ & $\begin{array}{c}(1) \\
25.0 \%\end{array}$ & & $\begin{array}{c}(4) \\
100.0 \%\end{array}$ \\
\hline Total & $\begin{array}{c}(20) \\
66.7 \%\end{array}$ & $\begin{array}{c}(10) \\
33.3 \%\end{array}$ & $\begin{array}{c}(30) \\
100.0 \%\end{array}$ & $\begin{array}{c}(10) \\
33.3 \%\end{array}$ & $\begin{array}{c}(4) \\
13.3 \%\end{array}$ & $\begin{array}{c}(7) \\
23.4 \%\end{array}$ & $\begin{array}{c}(9) \\
30.0 \%\end{array}$ & & $\begin{array}{c}(30) \\
100.0 \%\end{array}$ \\
\hline
\end{tabular}

( $\mathrm{P}>0.05$, non-significant $) \quad(\mathrm{P}>0.05$, non-significant $)$

EGFR expression and intensity in endometrial cancer according muscle invasiveness was found that among invasive endometrial cancer patients, 10(71.4\%) cases of them were found to be EGFR positive, while 10 $(62.5 \%)$ cases of non-invasive cases were found to be EGFR positive. Appreciation of EGFR expression intensity in endometrial cancer tumors in relation to invasiveness of tumor revealed that; in the invasive tumors, $4(28.5 \%)$ cases with score $0,2(14.3 \%)$ cases with score $+1,4(28.6 \%)$ cases with score +2 and +3 . While in the non-invasive tumors , $6(37.5 \%)$ cases with score $0,2(12.5 \%)$ cases with score $+1,3(18.7 \%)$ cases with score +2 , and $5(31.3 \%)$ cases with score +3 . There were no significant to EGFR expression and intensity in endometrial cancer according muscle invasiveness $(\mathrm{P}>0.05)$ Table $(8)$. 
Table(8):EGFR expression and intensity in endometrial cancer according to muscle invasiveness

\begin{tabular}{|c|c|c|c|c|c|c|c|c|c|}
\hline $\begin{array}{c}\text { muscle } \\
\text { invasiveness }\end{array}$ & $\begin{array}{r}\text { Expr } \\
\text { No\% }\end{array}$ & $\begin{array}{l}\text { sion } \\
\text { No\% }\end{array}$ & $P$ value & $\begin{array}{c}0 \\
\text { No\% }\end{array}$ & 1 No\% & $\begin{array}{c}\text { Intensity } \\
2 \\
\text { No\% }\end{array}$ & $\begin{array}{r}3 \\
\text { No\% }\end{array}$ & $P$ value & Total \\
\hline Yes & $\begin{array}{c}(10) \\
71.4 \%\end{array}$ & $\begin{array}{c}(4) \\
28.6 \%\end{array}$ & $\mathrm{P}>0.05$ & $\begin{array}{c}(4) \\
28.6 \%\end{array}$ & $\begin{array}{c}(2) \\
14.3 \%\end{array}$ & $\begin{array}{c}(4) \\
28.6 \%\end{array}$ & $\begin{array}{c}(4) \\
28.6 \%\end{array}$ & $\mathrm{P}>0.05$ & $\begin{array}{c}(14) \\
100.0 \%\end{array}$ \\
\hline No & $\begin{array}{c}(10) \\
62.5 \%\end{array}$ & $\begin{array}{c}(6) \\
37.5 \%\end{array}$ & & $\begin{array}{c}6) \\
37.5 \%\end{array}$ & $\begin{array}{c}(2) \\
12.5 \%\end{array}$ & $\begin{array}{c}(3) \\
18.7 \%\end{array}$ & $\begin{array}{c}(5) \\
31.3 \%\end{array}$ & & $\begin{array}{c}(16) \\
100.0 \%\end{array}$ \\
\hline Total & $\begin{array}{c}(20) \\
66.7 \%\end{array}$ & $\begin{array}{c}(10) \\
33.3 \%\end{array}$ & $\begin{array}{c}(30) \\
100.0 \%\end{array}$ & $\begin{array}{c}(10) \\
33.3 \%\end{array}$ & $\begin{array}{c}(4) \\
13.5 \%\end{array}$ & $\begin{array}{c}(7) \\
23.3 \%\end{array}$ & $\begin{array}{c}(9) \\
30.0 \%\end{array}$ & & $\begin{array}{c}(30) \\
100.0 \%\end{array}$ \\
\hline
\end{tabular}

EGFR expression and intensity in endometrial cancer according lymph node invasionwas reported that among lymph node invasive endometrial cancer patients,4(57.1\%) cases of them were found to be EGFR positive, while $16(69.6 \%)$ cases of non-invasive cases were found to be EGFR positive. Appreciation of EGFR expression intensity in endometrial cancer tumors in relation to lymph node invasiveness of tumor revealed that; in the invasive tumors,3(42.9\%) cases with score $0,2(28.5 \%)$ cases with score $+1,1(14.3 \%)$ cases with score +2 and 3 . While in the non-invasive tumors, $7(30.4 \%)$ cases with score $0,2(8.7 \%)$ cases with score $+1,6(26.0 \%)$ cases with score +2 and $8(34.8 \%)$ cases with score +3 . There were no significant to EGFR expression and intensity in endometrial cancer according lymph node invasion $(\mathrm{P}>0.05)$ Table $(9)$.

Table(9): EGFR expression and intensity in endometrial cancer according to lymph node invasion

\begin{tabular}{|c|c|c|c|c|c|c|c|c|c|}
\hline \multirow[b]{2}{*}{$\begin{array}{l}\text { lymph } \\
\text { node }\end{array}$} & \multicolumn{2}{|c|}{$\begin{array}{c}\text { Expression } \\
+\end{array}$} & \multirow[b]{2}{*}{$P$ value } & \multirow[b]{2}{*}{$\begin{array}{c}0 \\
\text { No\% }\end{array}$} & \multicolumn{3}{|c|}{ Intensity } & \multirow[b]{2}{*}{$P$ value } & \multirow[b]{2}{*}{ Total } \\
\hline & $\begin{array}{r}+ \\
\text { No\% }\end{array}$ & No\% & & & 1 No\% & $\begin{array}{c}1 \\
\text { No\% }\end{array}$ & $\begin{array}{c}3 \\
\text { No\% }\end{array}$ & & \\
\hline Yes & $\begin{array}{c}(4) \\
57.1 \%\end{array}$ & $\begin{array}{c}(3) \\
42.9 \%\end{array}$ & $\mathrm{P}>0.05$ & $\begin{array}{c}(3) \\
42.9 \%\end{array}$ & $\begin{array}{c}(2) \\
28.5 \%\end{array}$ & $\begin{array}{c}(1) \\
14.3 \%\end{array}$ & $\begin{array}{c}(1) \\
14.3 \%\end{array}$ & $\mathrm{P}>0.05$ & $\begin{array}{c}\text { (7) } \\
100.0 \%\end{array}$ \\
\hline No & $\begin{array}{c}(16) \\
69.6 \%\end{array}$ & $\begin{array}{c}(7) \\
30.4 \%\end{array}$ & & $\begin{array}{c}(7) \\
30.4 \%\end{array}$ & $\begin{array}{c}(2) \\
8.7 \%\end{array}$ & $\begin{array}{c}(6) \\
26.0 \%\end{array}$ & $\begin{array}{c}8) \\
34.8 \%\end{array}$ & & $\begin{array}{c}(23) \\
100.0 \%\end{array}$ \\
\hline Total & $\begin{array}{c}(20) \\
66.7 \%\end{array}$ & $\begin{array}{c}(10) \\
33.3 \%\end{array}$ & $\begin{array}{c}(30) \\
100.0 \%\end{array}$ & $\begin{array}{c}(10) \\
33.3 \%\end{array}$ & $\begin{array}{c}(4) \\
13.3 \%\end{array}$ & $\begin{array}{c}(7) \\
23.3 \%\end{array}$ & $\begin{array}{c}(9) \\
30.0 \%\end{array}$ & & $\begin{array}{c}(30) \\
100.0 \%\end{array}$ \\
\hline
\end{tabular}

Expression of EGFR reported positive in 2(\%28.6) out of 7 cases of papillary, and positive in $15(75.0 \%)$ out of 20 cases of endometriod, all patients 2(\%100)cases withsquamous cell carcinoma(SCC) and mucinous $1(100 \%)$ case were appeared positiveforEGFR expression.Intensity assessment of EGFR expression in endometrial cancer according histological type showed that; in papillary $5(71.4 \%)$ cases were scored $0,0(0 \%)$ case was scored $+1,1(14.3 \%)$ case was scored +2 and +3 . While in endometriod $5(25.0 \%)$ cases were scored 0 and +2 , $4(20.0 \%)$ cases were scored $+1,5(33.3 \%)$ cases were scored +2 , and $6(30.0 \%)$ cases were scored +3 , allsquamous cell carcinoma $2(\% 100)$ cases were scored +3 . In mucinous, the case $(100 \%)$ was scored +2 . There were no significant toEGFR expression and intensity of in endometrial cancer according histological type $(\mathrm{P}>0.05)$ Table (10) Fig (2).

Table(10):EGFR expression and intensity in endometrial cancer according to histological type

\begin{tabular}{|c|c|c|c|c|c|c|c|c|c|}
\hline \multirow{3}{*}{$\begin{array}{c}\begin{array}{c}\text { Histological } \\
\text { type }\end{array} \\
\text { Papillary }\end{array}$} & \multicolumn{2}{|c|}{ Expression } & \multirow{3}{*}{$\begin{array}{l}\text { P value } \\
\mathrm{P}>0.05\end{array}$} & \multirow{3}{*}{$\begin{array}{c}0 \\
\text { No\% } \\
(5) \\
71.4 \%\end{array}$} & \multicolumn{3}{|c|}{ Intensity } & \multirow{3}{*}{$\begin{array}{l}\text { P value } \\
P>0.05\end{array}$} & \multirow{3}{*}{$\begin{array}{c}\text { Total } \\
(7) \\
100.0 \%\end{array}$} \\
\hline & \multicolumn{2}{|c|}{ No\% } & & & $\begin{array}{c}1 \\
\text { No\% }\end{array}$ & & $\begin{array}{c}3 \\
\text { No\% }\end{array}$ & & \\
\hline & $\begin{array}{c}(2) \\
28.6 \%\end{array}$ & $\begin{array}{c}(5) \\
71.4 \%\end{array}$ & & & $\begin{array}{c}(0) \\
0.0 \%\end{array}$ & $\begin{array}{c}(1) \\
14.3 \%\end{array}$ & $\begin{array}{c}(1) \\
14.3 \%\end{array}$ & & \\
\hline Endometriod & $\begin{array}{c}(15) \\
75.0 \%\end{array}$ & $\begin{array}{c}5) \\
25.0 \%\end{array}$ & & $\begin{array}{c}5) \\
25.0 \%\end{array}$ & $\begin{array}{c}(4) \\
20.0 \%\end{array}$ & $\begin{array}{c}(5) \\
25.0 \%\end{array}$ & $\begin{array}{c}(6) \\
30.0 \%\end{array}$ & & $\begin{array}{c}(20) \\
100.0 \%\end{array}$ \\
\hline $\begin{array}{c}\text { Squamous } \\
\text { Cell } \\
\text { Carcinoma }\end{array}$ & $\begin{array}{c}(2) \\
100.0 \%\end{array}$ & $\begin{array}{c}(0) \\
0.0 \%\end{array}$ & & $\begin{array}{c}(0) \\
0.0 \%\end{array}$ & $\begin{array}{c}(0) \\
0.0 \%\end{array}$ & $\begin{array}{c}(0) \\
0.0 \%\end{array}$ & $\begin{array}{c}(2) \\
100.0 \%\end{array}$ & & $\begin{array}{c}(2) \\
100.0 \%\end{array}$ \\
\hline Mucinous & $\begin{array}{c}(1) \\
100.0 \%\end{array}$ & $\begin{array}{c}(0) \\
0.0 \%\end{array}$ & & $\begin{array}{c}(0) \\
0.0 \%\end{array}$ & $\begin{array}{c}(0) \\
0.0 \%\end{array}$ & $\begin{array}{c}(1) \\
100.0 \%\end{array}$ & $\begin{array}{c}(0) \\
0.0 \%\end{array}$ & & $\begin{array}{c}(1) \\
100.0 \%\end{array}$ \\
\hline Total & $\begin{array}{c}(20) \\
66.7 \%\end{array}$ & $\begin{array}{c}(10) \\
33.3 \%\end{array}$ & $\begin{array}{c}(30) \\
100.0 \%\end{array}$ & $\begin{array}{c}(10) \\
33.3 \%\end{array}$ & $\begin{array}{c}(4) \\
13.3 \%\end{array}$ & $\begin{array}{c}(7) \\
23.4 \%\end{array}$ & $\begin{array}{c}(9) \\
30.0 \%\end{array}$ & & $\begin{array}{c}(30) \\
100.0 \%\end{array}$ \\
\hline
\end{tabular}




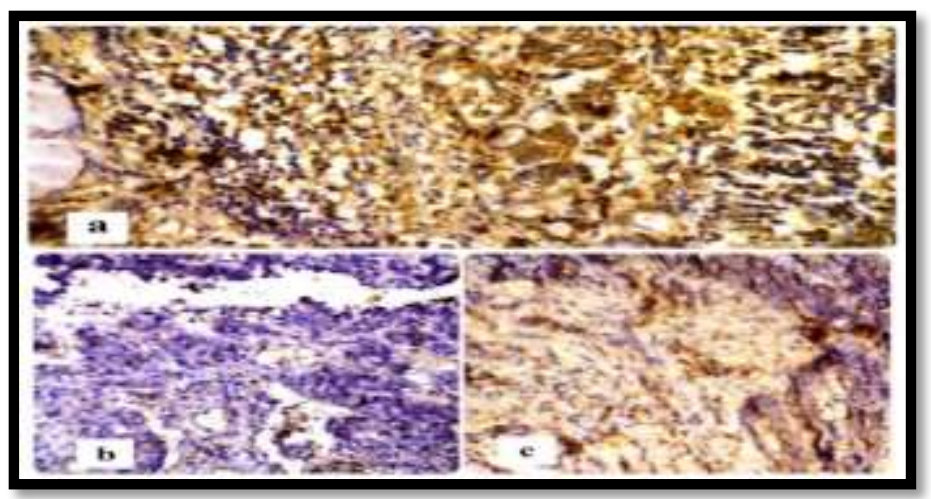

Figure(2):Positive EGFR IHC staining in endometrial patients according histological type a. Papillary, b. Endometriod, c. Mucinous (x40).

Our results found no significant to EGFR expression and intensity according to all pathological parameters, staging, grading, muscles and lymph nodes invasion and histological types ( $P>0.05$ ) (Table 6,7,8,9 and 10).[28] reported thatEGFR expression positive were (22) cases in stage II , while in stage III were positive (18) cases.In addition[29] explained that expression for EGFR in normal endometrial membrane and its overexpression is linked with the stage of endometrial cancer and a poor prognosis . Overexpression for EGFR in endometrial cancer is the important member of ErbB/HER receptor tyrosine kinase family, which has been showed to contributed in the development of human cancer [34].Results of[28]found in grade $\mathrm{I}(\mathrm{n}=29)$,EGFRexpression positive was in (18) cases and negative (11),ingrade IIand grade III(n=27),EGFR expression positive were in (22) cases.Moreover, [12] reported that EGFR expression positive were in 28(55.0\%) cases out of 51 in gradeI, 23(44.0\%) cases out of 52 in grade II, $45(33.0 \%)$ cases out of 138 in gradeII. In addition [26] EGFR protein was highly expressed in low grade( grade I and grade II) and high grade in endometriod carcinoma,this is due to EGFR intermediates the activation of intracellular signaling pathways, resulting in promoted proliferation and cell survival in endometriod carcinoma cells, together with these results enhanced more the importance of EGFR in the proliferation of low grade in endometriod tumor [26].Also,[27]reported that positive expression for EGFR in the G III endometrial carcinoma tissues was significantly higher than that in grade I $(\mathrm{P}<0.01)$, as well as found significant between GI and GII $(\mathrm{P}<$ 0.05 ).Moreover, our results showed no significant to EGFR expression and intensity according muscle and lymph node invasiveness $(\mathrm{P}>0.05$. Results of [27] found thatthe positive expression for EGFR in the $>1 / 2$ myometrial invasion group was higher than that in the $\leq 1 / 2$ myometrial invasion group $(\mathrm{P}<0.01)$. In addition,[30] explained that the myometrial invasion was (8) cases in internal half of the thickness of the myometrium, while (3) cases in the invasion was present in half of its external layer. On the other hand, results of[31] found that 165 patients were having negative lymph nodes and 38having positive lymph nodes out of 203 withendometrial cancer and showed the genes specified to be independently related with lymph node metastasis alsodepth of myometrial invasion was the single clinicopathological parameter to be independently related with lymph node metastasis. In addition [32] explained that highly expression for EGFR in the metastatic lymph node was linked with comparatively poor survival and give added risk of death.Moreover, [27]reported thatthe expression of EGFR had no correlation with the FIGO stage and the lymph node metastasis of endometrial carcinoma. However,our results showed no significant toEGFR expression and intensity in endometrial cancer according histological type ( $\mathrm{P}>0.05$. Results of 12$]$ found that EGFR expression was lower in type II $(34 \%)$ compared with type I EC (46\%) and reported that EGFR expression positive in 60(46\%)cases endometriod out of 130 and 36(36\%) cases uterine serous papillary out of 101.[33] explain that EGFR expression was found in 60 $(59.4 \%)$ cases out of 101 ofsquamous cell carcinoma. Our findings explain clearly, that the development and progression of endometrial cancer did not affected by p53 and EGFR expression; also these results need other confirmations.

\section{Conclusion}

In conclusion, the present study confirms that development and progression of the endometrial carcinoma does not depend on, histopathological variables (stage, grade, and depth of muscle and lymph nodes invasiveness.

\section{Acknowledgement}

We would like to express special thanks to Mr. Younis Atiyah Kamil, Dr. Ali AbidSaadonAl-Ghuzy /Thi Qar University /College of Medicine/Vice dean for scientific and Dr. Dr. Hameed Naeem Mousa from College of Medicine ,University of Thi Qar ,for their helping in the patients diagnosis and statistical analysis 


\section{References}

[1]. Siegel, R. ;Naishadham ,D. and Jemal, A.(2012). Cancer statistics,2012. CA Cancer JClin. 62(1),10-29.

[2]. Lee, N.K.; Cheung, M.K.; Shin, J.Y. et al.(2007). Prognostic factors for uterine cancer inreproductive-aged women. Obstet Gynecol . 109, 655-662.

[3]. Sweet, M.G.; Schmidt-Dalton ,T.A.; Weiss, P.M. and Madsen, K.P.(2012).Evaluation and management of abnormal uterine bleeding in premenopausal women.Am Fam Physician. Jan 85(1), 35-43.

[4]. Ward,k.k.et al.(2012).cardiovascular disease is the leading cause of death among endometrial cancer patients.Gynecol Oncol 126,176-9.

[5]. Wright, J.D.; BarrenaMedel,N.I .; Sehouli, J.; Fujiwara, K. and Herzog, T.J. (2012).Contemporary management of endometrial cancer. Lancet 379 (9823), 1352-60.

[6]. Tirumani, S.H.; Shanbhogue, A.K. and Prasad, S.R. (2013).Current concepts in the diagnosis and management of endometrial and cervical carcinomas. Radiol Clin North Am .51, 1087-110.

[7]. Sorosky, J.I.(2012) .Endometrial cancer. Obstetrics \& Gynecology.120, 383-397.

[8]. Ascher, S.M .and Reinhold, C.(2002). Imaging of cancer of the endometrium. Radiol Clin North Am .40(12), 563-76.

[9]. Zheltukhin, A. O. and Chumakov P. M. (2010). Constitutive and induced functions of the p53 gene. Biochemistry (Mosc). 75, $1692-1721+64$.

[10]. Janiec-Jankowska, A.; Konopka, B.; Goluda, C. and Najmoła, U. (2010) .Tp53mutations in endometrial cancers: relation to PTEN gene defects. International Journal of Gynecological Cancer. 20(2), 196-202.

[11]. Akbalik ,M.E. and Ketani, M.A. (2013). Expression of epidermal growth factor receptors and epidermal growth factor, amphiregulin and neuregulin in bovine uteroplacental tissues during gestation. Placenta, 34, 1232-1242.

[12]. Konecny, G.; Santos, L.; Winterhoff, B. and et al.(2009). HER2 gene amplification and EGFR expression in a large cohort of surgically staged patients with non endometrioid (type II) endometrial cancer. Br J Cancer .100, 89-95.

[13]. Androutsopoulos, G. ; Adonakis, G.; Liava, A.; Ravazoula ,P. and Decavalas ,G. (2013).Expression and potential role of ErbB receptors in type II endometrial cancer. Eur J Obstet Gynecol Reprod Biol .168, 204-08.

[14]. Fadare ,O.; Gwin , K.; Mohamed M. Desouki ,M.M.; Crispens, M.A.; Jones, H.W.; Khabele, D.; Liang ,S.X. ; Zheng, W.; Mohammed, K.; Hecht ,J.L. and Parkash ,V.(2013).The Clinicopathologic Significance of p53 and BAF-250a (ARID1A) expression in clear cell carcinoma of the endometrium.Modern Pathology. 26(8), 1101-1110.

[15]. Daniilidou, K.; Frangou- Plemenou, M.; Grammatikakis ,J. Grigoriou, O.; Vitoratos, N. and Kondi-Pafiti, A.(2013). Prognostic significance and diagnostic value of PTEN and p53 expression in endometrial carcinoma. A retrospective clinicopathological and immunohistochemical study. J BUON . 18(1), 195-201.

[16]. El-Shorbagy, S.H.Orieby ,R. and EL-Shorbagy, Sh.H.(2016).Expression of hormone receptors; p53 and CD44 in endometrial carcinoma and their prognostic significance.Life Sci J .13(4), 94-104.

[17]. Kounelis ,S.; Kapranos ,N.; Kouri ,E. ; Coppola , D.; Papadaki ,H. ; Jones, M.W.(2000). Immunohistochemical profile of endometrial adenocarcinoma: a study of 61 cases and review of the literature. Mod Pathol J.13(4), 379-388

[18]. Ahmed ,N .Y and Isaac,R.H.(2010).P53 expression in endometrial hyperplasia and endometrial carcinoma.Zanco J. Med. Sci.14(2).

[19]. Fyallah , E.A. ; Hemida, R.A. ; Anwar, K.I.; Nadia, N.A.; Sherif, L.S. and Sayed- Ahmed ,M.T.(2011). Preoperative evaluation of P53 and bcl-2 over expression in clinical stage 1 endometrial carcinoma and their correlation with surgico-pathological data and prognosis of patients. Open Journal of Obstetrics and Gynecology. 1, 55-63.

[20]. Jeon ,Y.T.; Kang ,S.; Kang ,D.H.; Yoo ,K.Y.; Park ,I.A.; Bang,Y.J.; Kim ,J.W.; Park ,N.H.; Kang ,S.B.; Lee ,H. P. and Song ,Y.S.(2004). Cyclooxygenase-2 and p53 expressions in endometrial cancer. Cancer Epidemiology Biomarkers \& Prevention.13(9), $1538-1542$.

[21]. Ragni, N. ; Ferrero, S. ; Prefumo ,F. ; Muschiato „B. ; Gorlero „F. ; Gualco ,M. and Fulcheri ,E.(2005). The association between p53 expression, stage and histological features in endometrial cancer. European Journal of Obstetrics \& Gynecology and Reproductive Biology. 123 (1), 111-116.

[22]. Yemelyanova, A.; Vang, R.; Kshirsagar ,M.; Lu, D.; Marks, M.A.; Shih, M. and Kurman, R.J.(2011). Immunohistochemical staining patterns of p53 can serve as a surrogate marker for TP53 mutations in ovarian carcinoma: an immunohistochemical and nucleotide sequencing analysis. Mod Pathol. 24(9), 1248-1253.

[23]. McCluggage, W.G.; Connolly, L.E.; McBride ,H.A.; Kalloger, S. and Gilks,C.B.(2012). HMGA2 is commonly expressed in uterine serous carcinomas and is a useful adjunct to diagnosis. Histopathology. 60(4), 547-553.

[24]. Terada ,T. and Tateoka ,K.(2013).Primary pure squamous cell carcinoma of the endometrium: a case report. Int J Clin Exp Pathol. 6(5), 990-993.

[25]. Shih, L. and Kurman, R. (2004).Ovarian tumorigenesis: a proposed model based on morphological and molecular genetic analysis. Am J Pathol.164(5), 1511-1518.

[26]. Nishimura ,T.; Nakamura, K.; Yamashita, S.; Ikeda, S.; Kigure, K. and Minegishi ,T. (2015). Effect of the molecular targeted drug, erlotinib, against endometrial cancer expressing high levels of epidermal growth factor receptor. BMC Cancer. $15,957$.

[27]. Zhang,L. and Fu ,F.(2013). EGFR protein expression and EGFR gene mutation in endometrial carcinoma. Chinese Journal of Cancer Biotherapy. 20(1), 99-104.

[28]. Ai, Z.; Wang ,J. ; Wang, Y.; Lu, L.; Tong ,J.; and Teng, Y.(2010).Overexpressed Epidermal Growth Factor Receptor (EGFR)induced progestin insensitivity in human endometrial carcinoma cells by the EGFR/mitogen-activated protein kinase signaling pathway.American Cancer Society.116, 3603-3613

[29]. Zagouri F.; Bozas G.; Kafantari E.; Tsiatas,M.; Nikitas,N.;Dimopoulos, M.A. and Papadimitriou, C.A.(2010). Endometrial cancer: what isnew in adjuvant and molecularly targeted therapy? Obstet Gynecol Int.2010,11.

[30]. Stoian ,S.C. ; Simionescu ,C.; Margaritescu, C.; Stepan, A. and Nurciu, M.(2011). Endometrial carcinomas: correlation between ER, PR, Ki67 status and histopathological prognostic parameters.Rom J MorpholEmbryol . 52(2), 631-636.

[31]. Zgheib, N.B.; Marchion ,D.C.; BUSH,S.H.; Judson ,P.L.; Wenham ,R.M.; Apte ,S.M.; Lancaster ,J.M. and Bosquet ,J.G.(2016). Molecular determinants for lymphnode metastasis in clinically early-stage endometrial cancer. Oncol Lett.11(1), 323-329.

[32]. Deng, Y.; Kurland ,B.F.; Wang, J.; Bi, J.; Li, W. ;Rao, S.; Lan, P.; Lin, T. and Lin, E.(2009). High epidermal growth factor receptor expression in metastatic cancer lymph nodes may be more prognostic of poor survival than in primary tumor. Am $\mathrm{J}$ Clin Oncol. 32(3), 245-252.

[33]. Bumrungthai, S.; Munjal, K.; Nandekar, S; Cooper, K.; Ekalaksananan, T.; Pientong ,C. and Evans ,M.F.(2015). Epidermal growth factor receptor pathwaymutation and expression profiles in cervical squamous cell carcinoma: therapeutic implications. Journal of Translational Medicine. 13, 244

[34]. Herbst,R.S.(2004). Review of epidermal growth factor receptor biology. Int J Radiat Oncol Biol Phys .59, $21-26$.

DOI: $10.9790 / 0853-1601073139 \quad$ www.iosrjournals.org $39 \mid$ Page

